\title{
EVALUATION OF CALORIFIC VALUE OF BIO-BRIQUETTE
}

\author{
G. Sireesh Kumar ${ }^{1}$, C.J.Rao ${ }^{2}$, S.K.Madhavi ${ }^{3}$ \\ ${ }^{1}$ M.Tech Student, Department of Mechanical Engineering, AITAM Engineering College, Andhra Pradesh India \\ ${ }^{2}$ Professor, HOD, Department of Mechanical Engineering, AITAM Engineering College, Andhra Pradesh India \\ ${ }^{3}$ AssistantProfessor Department of Mechanical Engineering, AITAM Engineering College, Andhra Pradesh India
}

\begin{abstract}
In developing countries more wastage is obtaining such as solid municipal wastage, agricultural wastages etc., and the problem of dumping arises. The effective utilization of that waste can solve that problem and also we generate power from those wastes. Hence the concept of bio-briquettes was introduced. Various technologies were used to made the briquettes such as screw extrusion, ramming, hydraulic pressing etc., At present briquettes are preparing from saw dust, rice husk, oil mill sludge etc., My paper presents the briquettes made from the palm tree branches mixed with coconut coir, saw dust, screw pine, Indian Bdellium tree powder in different proportions. The briquettes prepared in the different ratios of 100:0 with and without binder $\left(P_{W 100}, P_{W 0100}\right), 100: 50\left(P_{W 50}\right), 100: 20$ with and without binder $\left(P_{W 20}, P_{W 020}\right), 0: 100$ by using only additives $\left(A_{W 100}\right)$. The proximate analysis was conducted and those are compared with the Indian coal. The moisture content is high for $A_{W 100}(8.53 \%)$, ash content is for $A_{W 100}(12.2 \%)$, volatile content is for $P_{W B 100}(86.9 \%)$,fixed carbon is for $P_{W 20}(17.38 \%)$ and calorific value $K J / K G$ is for $P_{\text {WOI0o }}(19,351)$.
\end{abstract}

Keywords: Bio-Briquettes, Palm Tree Branches, Coconut Coir, Saw Dust, Screw Pine, Indian Bdellium Tree Powder, Proximate Analysis

\section{INTRODUCTION}

Resources of energy are classified into renewable and non renewable. The non renewable resources will exhaust in future. Hence we will go for renewable energy resources. If we can substitute the renewable resources to non-renewable at present for smaller applications we may increase the exhaust period of non-renewable resources. As India is agricultural based developing country so there is a lot of solid agricultural wastage occurs. If we burn the agro wastes that cause a lot of pollution. And they burn quickly. Hence conversion to dense briquettes may reduce the pollution and increases the burning time, and that will be a substitute for non-renewable energy resources. Briquette is a material which is prepared by the densification of loose agro wastes into a dense, compact solid material under high pressure. It has high density, energy and has lesser moisture content. Several technologies were used in making of briquettes such as screw extrusion technology, ramming process, etc. These are all prepared by two methods i.e. with and without preheating die (S.C. Bhattacharya et al.,, 1998). Briquettes can be made from rice husk, groundnut shell, paper, sugarcane wastes, saw dust, crop wastes, etc. Briquettes also made by mixing those wastes with coal, lignite, seaweeds etc. Briquettes can be done with binder material and without using binder materials (DENG Yunpeng, at et al.,, 2012). Generally starch is used as binder (UGWU et al.,, 2011).

Biomass briquettes are used for both small and large scale purposes such as cooking combustion in boilers to produce steam, power generation.

\section{LITERATURE SURVEY}

Peter Krizan et al.,, 2015 had observed the behavior of beech saw dust during densification and set a technical density value to $1.14 \mathrm{~kg} \cdot \mathrm{dm}^{-3}$. They determined the interaction among compression pressure, compression temperature, and material size during densification process.[3]

DahamShyamalee et al.,, 2015 prepared briquettes with binding agents like cow dung, wheat flour and paper pulp. These briquettes were tested for calorific value, compressive strength by varying percentage of binders and also calculated the minimum energy cost for production.[7]

WahidinNuriana et al.,, 2014 made briquettes from durian peel in cylindrical shape of $3.8 \mathrm{~cm}$ diameter, $6.5 \mathrm{~cm}$ high and 100 mesh grain size by carbonizing process and raised the fuel density and calorific value per volume.[8]

T.U. Onuegbu et al.,, 2012 had prepared bio briquettes (elephant grass and spear grass) and bio coal briquettes at moderate pressure and temperature. Carried proximate analysis and compared them with the wood samples. Their efforts are to substitute firewood to briquettes in the rural households in Nigeria.[1]

\section{PREPARATION OF BRIQUETTES}

Briquettes are prepared by using many wastes such as saw dust, rice husk papers etc., which are having some drawbacks such as if we use rice husk which contains silicon upon combustion produces silicon dioxide causes damages to the boiler shell. The saw dust briquettes are 
having low calorific value compared to others. Hence in this paper I used Palm branches mixed with coconut coir, saw dust, screw pine, Indian Bdellium tree powder with and without using binder material in different proportions. Screw pine, Indian Bdellium tree powder are used as they catch fire quickly, while saw dust and coconut nut coir give more density to briquettes.

The raw materials are palm branches, coconut coir, saw dust, screw pine, Indian Bdellium tree powder. The palm branches are dried and chopped into a fine powder by using paper machine. Then that powder is dried to remove themoisture content for 3-4 days. In the same manner the other ingredients are also dried for 3-4 days. (Fig.A)

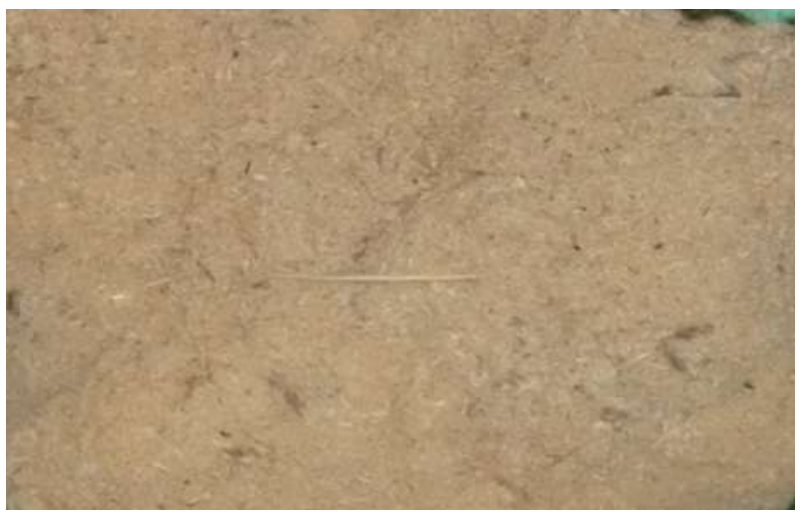

Fig A) Palm Branch Powder

The die is of cylindrical in shape having dimensions of 15 $\mathrm{cm}$ (nearly 6 inches) diameter, $30.5 \mathrm{~cm}$ (12inches) height. The interior of die is very smooth. (Fig. B, C).

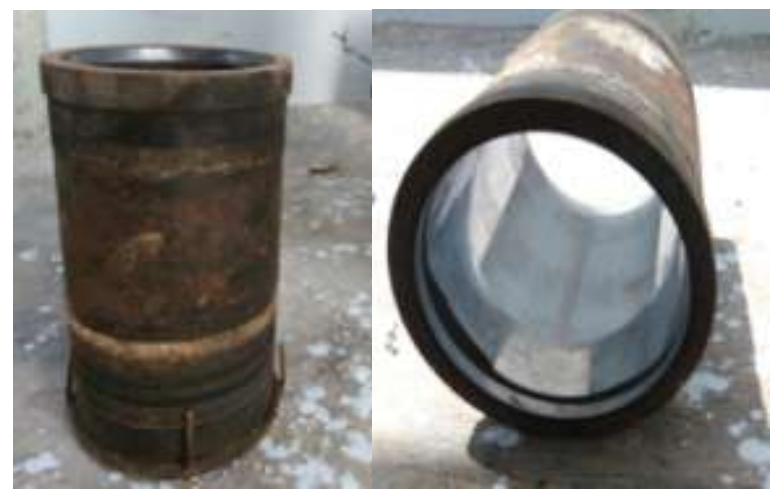

Figs B) Die

Fig C) Interior of Die

Many techniques are used such as ramming, screw press extrusion technique by preheating die and without preheating die. Other techniques like Peterson press (Daham Shyamalee et al.,, 2015), hydraulic press(C. Supann et al.,, 2008). Basing on all the equipment designs I prepared my own set up for briquette preparation. The set up is prepared by using iron channels of $10 \mathrm{~cm}$ ( 4 inches) width. Two iron channels of $127 \mathrm{~cm}$ (50 inches) long, other two iron channel of $46 \mathrm{~cm}$ (18 inches), $61 \mathrm{~cm}$ (24 inches) are taken and welded as shown in figure D. A 100 ton hydraulic jack is used for compressing the material. A supporting rod is used and the total set up is arranged as shown in the figure E.

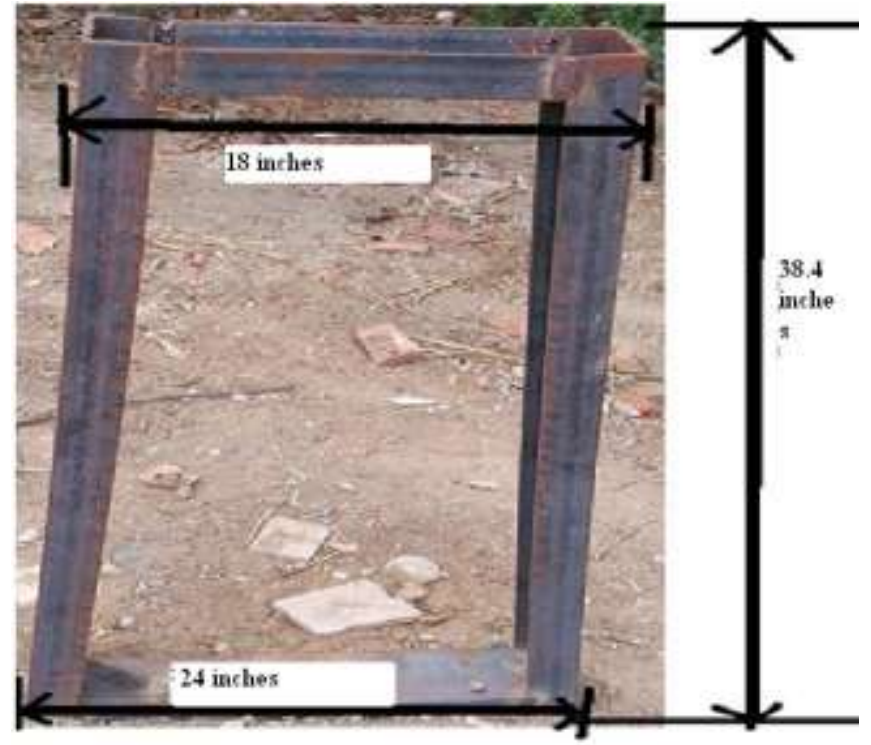

Fig D) Set Up

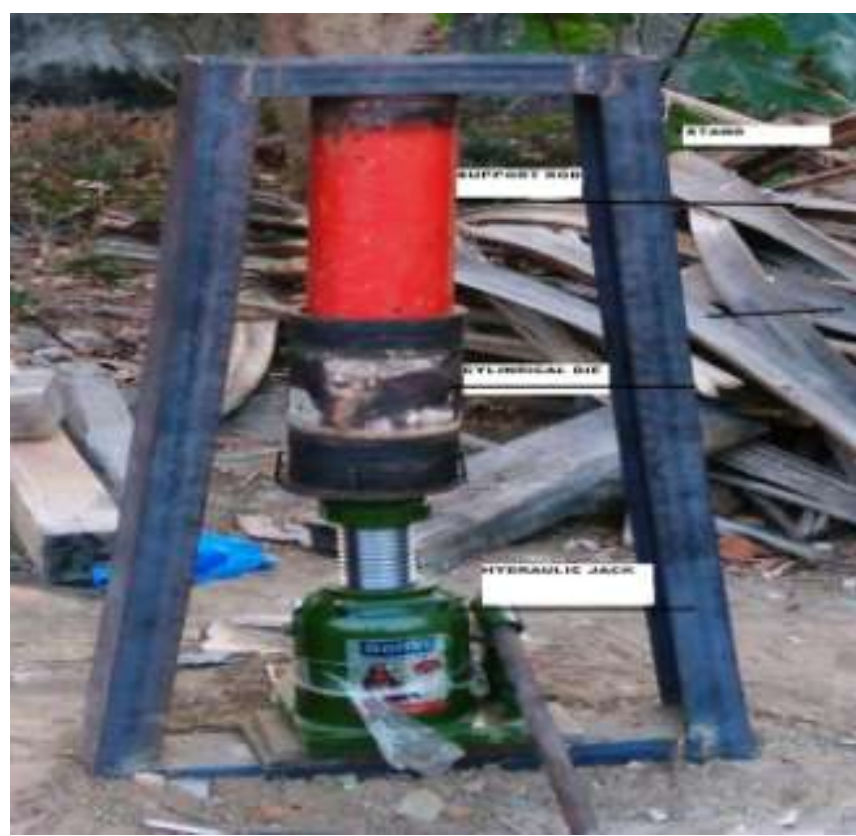

Fig E)Set Up With Die

After the set up preparation the binder material is to be prepared from Maida flour poured in boiling water and the boiled starch are mixed with each other in the ratio of $1: 1$ until we get a paste. The saw dust, coconut coir powder, screw pine powder and bdellium powder are mixed in the ratio of $1: 2: 2: 1$. This mixture is again mixed with palm in different ratios of 100:0 with and without binder, 100:50 with binder, 100:20 with and without binder, 0:100(only additives). The binder is mixed in the ratio of 10:1. And that mixture is dried for 2 hrs.

Then the mixture of net weight of $500 \mathrm{gm}$ is taken in the die and placed as shown in the Figure E. Then by using the hydraulic jack compress the mixture with its maximum power of 100 ton. We can get the briquette and it is kept under that pressure for a period of $12 \mathrm{hrs}$ then release the pressure and take out the briquette from the die. 
Table 1: Briquette Ratio and Composition

\begin{tabular}{|c|c|}
\hline $\begin{array}{l}\text { BRIQUETTE } \\
\text { MATERIAL } \\
\text { RATIO }\end{array}$ & COMPOSITION \\
\hline 100:0 $\quad \mathrm{P}_{\mathrm{W} 100}$ & Pure palm powder with binder \\
\hline 100:0 $\quad \mathrm{P}_{\mathrm{WO} 100}$ & Pure palm powder without binder \\
\hline $100: 50 \mathrm{P}_{\mathrm{W} 50}$ & $\begin{array}{l}\text { Palm powder mixed with } \\
50 \% \text { additives with binder }\end{array}$ \\
\hline $100: 20 \quad P_{\mathrm{W} 20}$ & $\begin{array}{l}\text { Palm powder mixed with } \\
20 \% \text { additives with binder }\end{array}$ \\
\hline $100: 20 \mathrm{P}_{\mathrm{WO} 20}$ & $\begin{array}{l}\text { Palm powder mixed with } \\
20 \% \text { additives without binder }\end{array}$ \\
\hline $0: 100 \quad A_{W 100}$ & Pure additives only with binder \\
\hline
\end{tabular}

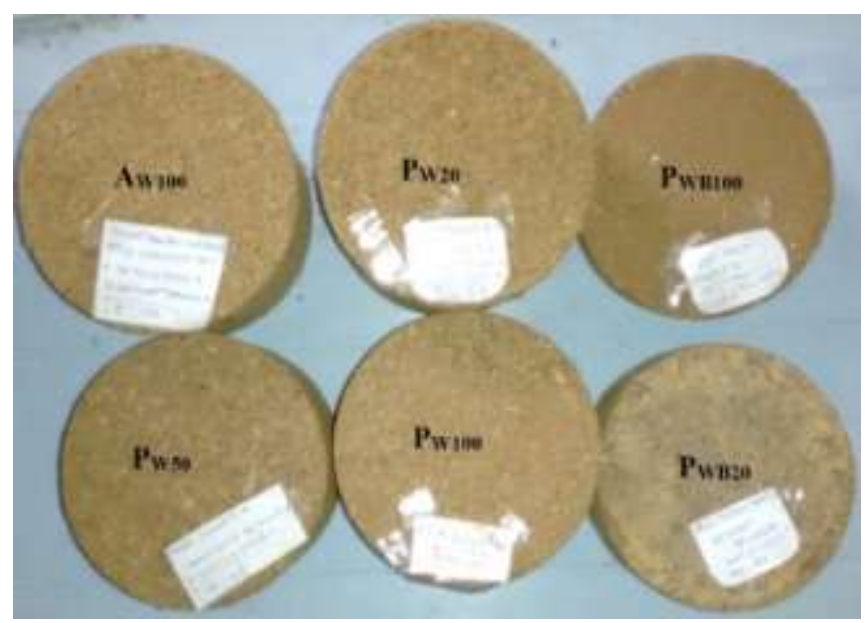

Fig F Briquettes with Different Ratios

\section{RESULTS AND DISCUSSION}

The briquettes are carried out for proximate analysis to get calorific value, fixed carbon content, volatile matter, ash content, moisture content. And those values are compared with Indian coal.

\subsection{Determination of Moisture}

The briquettes were heated to a temperature of $1050 \mathrm{C} \pm 50 \mathrm{C}$ for one hour in air oven. The briquettes were then taken out from the oven and the materials were weight. The percentage loss in weight was calculated which gives the percentage $(\%)$ moisture contains in the sample.

From the results we obtained the moisture is high for $\mathrm{A}_{100}(8.53)$ and Indian coal as 2.2.

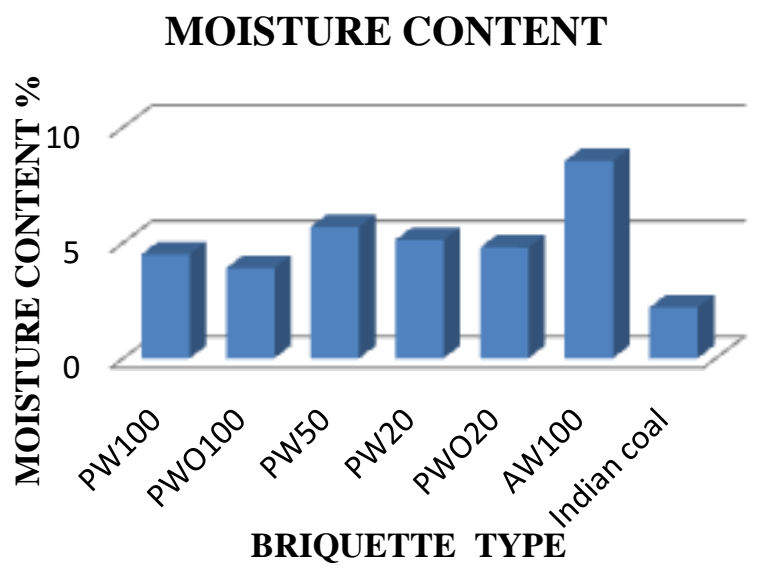

\subsection{Determination of Ash Content}

The briquettes are kept in a furnace and are burned completely in a closed furnace. The weight of the residue was taken in an electronic balance. The percentage weight of residue gives the ash contained in the sample. From the results we obtained the ash content is high for $\mathrm{A}_{100}$ as 12.2 and Indian coal as 27.8 .

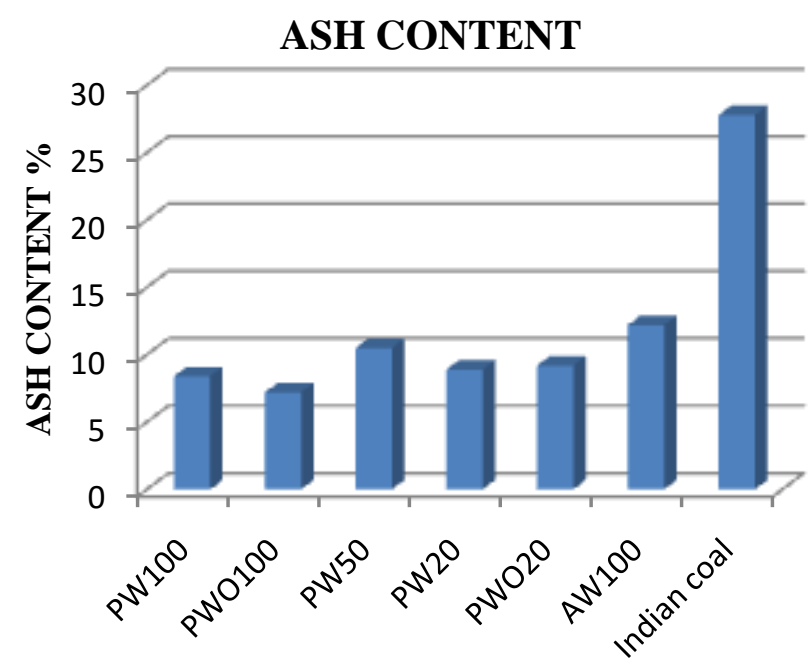

BRIQUETTE TYPE

\subsection{Determination of Volatile Matter}

The briquettes are kept in a furnace and are burned in a closed furnace for 7 minute at high temperatures. The volatile matter crucibles were then taken out from the furnace and cooled in air. The briquettes were weighted in an electronics balance and the percentage loss in weight in each of the Samples was calculated. The percentage volatile matter in the sample was determined by using the following formula

$\%$ volatile matter $(\mathrm{VM})=\%$ loss in weight $\%$ moisture 
From the results we obtained the volatile matter is high for $\mathrm{P}_{\mathrm{WO} 100}$ as 86.9 and Indian coal as 22.9.

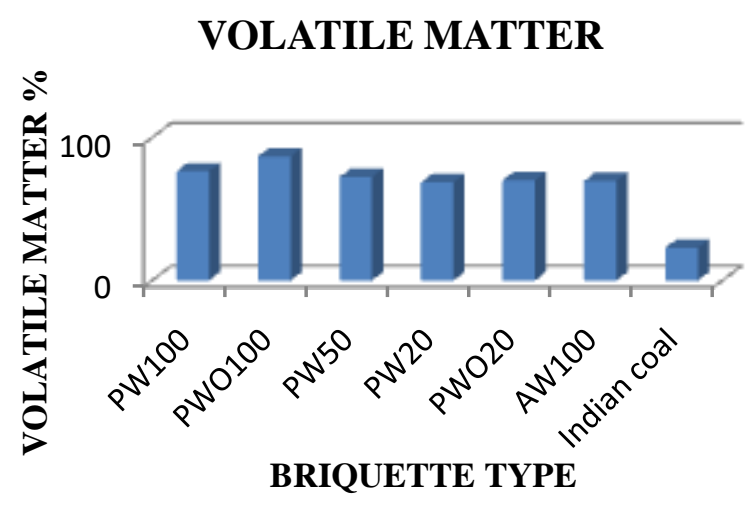

\subsection{Determination of Fixed Carbon}

The fixed carbons in the simple were determined by using the following formula.

$\% F C=100-(\% M+\% V M+\% A S H)$

Where, FC: Fixed carbon

M: Moisture

VM: Volatile Matter

ASH: Ash Content

From the results we obtained the fixed carbon is high for $\mathrm{P}_{\mathrm{W} 20}$ as 17.38 and Indian coal as 47.1.

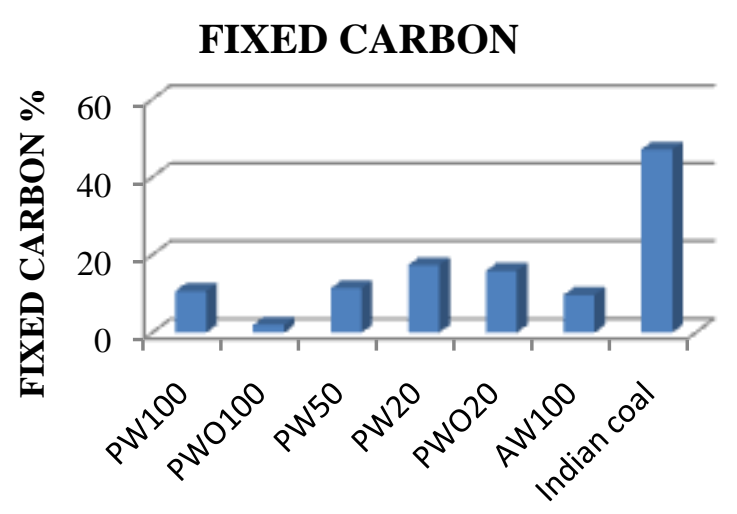

BRIQUETTE TYPE

\subsection{Calorific Value}

The calorific values of the each briquette is determined by using Bomb Calorimeter and the values from the results obtained for $P_{W 100}$ as $18,929 \mathrm{kj} / \mathrm{kg}, P_{W 0100}$ as $19,351 \mathrm{kj} / \mathrm{kg}$, $\mathrm{P}_{\mathrm{W} 50}$ as $17,894 \mathrm{kj} / \mathrm{kg}, \quad \mathrm{P}_{\mathrm{W} 20}$ as $18,118 \mathrm{kj} / \mathrm{kg}, \quad \mathrm{P}_{\mathrm{WO} 20}$ as $18,095 \mathrm{kj} / \mathrm{kg}, \mathrm{A}_{100}$ as $17,215 \mathrm{kj} / \mathrm{kg}$, and Indian coal as $22,255.82 \mathrm{kj} / \mathrm{kg}$. It is observed that Indian coal is having highest $\mathrm{CV}$ and the briquettes $\mathrm{P}_{\mathrm{WO100}}, \mathrm{P}_{\mathrm{W} 100}, \mathrm{P}_{\mathrm{W} 20}$, are nearer to that of the coal calorific value.

It is observed that Indian coal is having highest $\mathrm{CV}$ and the briquettes $\mathrm{P}_{\mathrm{WO100}}, \mathrm{P}_{\mathrm{W} 100}, \mathrm{P}_{\mathrm{W} 20}$, are nearer to that of the coal calorific value.

\section{CALORIFIC VALUE}

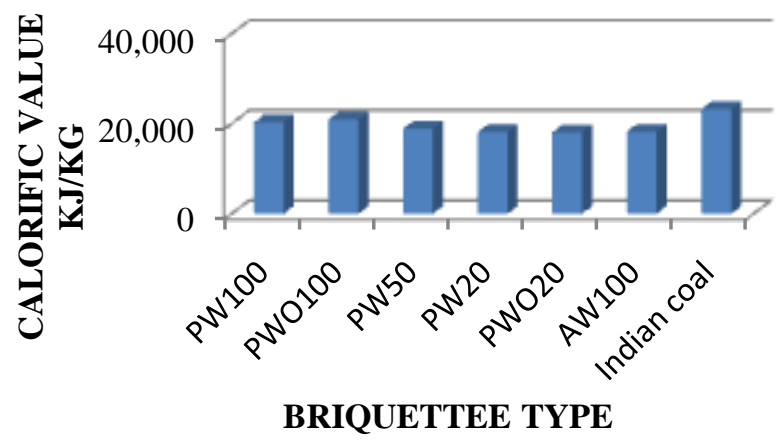

\section{CONCLUSION}

We can conclude that the solid wastage can be utilized into the useful energy conversion materials such as briquettes of different materials. In this project by using the palm tree branches mixed with coconut coir, saw dust, bdellium powder, and screw pine powder in different ratios. Calculated the proximate analysis and calorific values and from those values the calorific values of briquette from only palm powder with and without binder materials (100:0) are nearer to the $\mathrm{CV}$ of coal. i.e. the heat releasing rate will be nearer to that of coal. Henceforth we may use briquette as an alternate to coal in many of the industrial applications. As the carbon content is less hence emits less pollution upon combustionthan that of coal.

\section{REFERENCES}

[1] T.U. Onuegbu, I.M. Ogbu, and C. Ejikeme January 2012 comparative analyses of densities and calorific values of wood and briquettes samples prepared at moderate pressure and ambient temperature.

[2] Jaya Shankar Tumuluru Christopher T. Wright Kevin L. Kenny J. Richard Hess august 2010 A Review on Biomass Densification Technologies for Energy Application.

[3] Peter Krizan, Milos Matus, LubomirSoos and JurajBeniakjune 2015 Behavior of Beech Sawdust during Densification into a Solid Biofuel.

[4] Maninder, Rupinderjit Singh Kathuria, Sonia Grover august 2012 using Agricultural Residues as a Biomass Briquetting: An Alternative Source of Energy.

[5] UGWU, K E; AGBO, K E september 2011 Briquetting of Palm Kernel Shell.

[6] A.B.Nasrin, A.N.Ma, Y.M.Choo, S.Mohamad, M.H.Rohaya, A.Azali and Z.Zainal 2008 Oil Palm Biomass as Potential Substitution Raw Materials for Commercial Biomass Briquettes Production.

[7] DahamShyamalee, A.D.U.S. Amarasinghe, N.S. Senanayaka march 2015 Evaluation of different binding materials in forming biomass briquettes with saw dust.

[8] WahidinNuriana, NurfaAnisa, MartanaSynthesis Preliminary Studies 2014 Durian Peel Bio Briquettes as an Alternative Fuels. 
[9] H. Haykiri-Acma, S. Yaman, S. Kucukbayrak 2013 Production of biobriquettes from carbonized brown seaweed.

[10] Manoj Kumar Sharma, GohilPriyank, Nikita Sharma 2015 Biomass Briquette Production: A Propagation of Non-Convention Technology and Future of Pollution Free Thermal Energy Sources.

[11] T.U. Onuegbu U.E. Ekpunobi1, I.M. Ogbu1, M.O. Ekeoma\& F.O. Obumselu1may 2011 Comparative Studies Of Ignition Time And Water Boiling Test Of Coal And Biomass Briquettes Blend.

[12] Ch. A. I. Raju1, K. RamyaJyothi, M. Satya, U.PraveenaFeb. 2014 STUDIES ON DEVELOPMENT OF FUEL BRIQUETTES FORHOUSEHOLD AND INDUSTRIAL PURPOSE

[13] Emerhi, E. A. 2011 Physical and combustion properties of briquettes produced fromsawdust of three hardwood species and different organic binders

[14] K.Sivakumar1, B. Sivaraman and N.KrishnaMohan November 2011 Effectiveness of briquetting bio mass materials with different ratios in $10 \mathrm{kWdown}$ draft gasifier.

[15] IkelleIssieIkelle and OgahSule Philip Ivoms April 2014 Determination of the Heating Ability of Coal and Corn Cob Briquettes. 